\title{
Anticipace postsekularity v první Československé republice jako syntéza a východisko k světovosti české literatury
}

Ivo Pospíšil (Brno)

\begin{abstract}
Abstrakt
Autor prítomné studie vychází z teze, že období první Československé republiky bylo počátkem velké, spišš skryté syntézy vedoucí k budování světovosti české literatury a ke kladné kvalitativní změně slovenské literatury. Tato syntéza spočívala v prostupování levicové avantgardy a katolického spiritualismu, jež autor nevidí jako směry nejen protikladné, ale také komplementární s hlubinnými souvislostmi. Prostupování nespočívá jen v osobních vztazích tvưrců (Nezval, Halas, Deml, Zahradníček, Holan aj.), ale i v prolínání idejí a hlavně tvarů a estetických východisek. Cesta k světovosti české literatury je podle autora založena právě na budování tohoto silného vztahu a komplementárního, vícepramennéhoo celku, které anticipuje tzv. postsekularitu, která se projevuje v celém 20. století.
\end{abstract}

\section{Klíčová slova}

cesta české literatury k světovosti; podobné procesy v slovenské literatuře; duální vývoj české literatury; prostupování levicové avantgardy a spirituální literatury

\section{Abstract \\ The Anticipation of Postsecularity in the First Czechoslovak Republic as a Synthesis and a Starting Point for the Worldwide Reputation of Czech Literature}

The author of the present study expresses the thesis according to which the period of the first Czechoslovak Republic represented the beginning of a big, rather hidden synthesis leading to constructing the worldwide reputation of the Czech literature and to a positive qualitative change of the Slovak literature. The synthesis consisted in the permeation of the leftist avant-garde and Catholic spirituality the author regards not only as contradictory currents, but also as complementary ones with deep links. The permeation does not consist only in mutual personal relations of literary creators (Nezval, Halas, Deml, Zahradníček, Holan and others), but also in the permeation of ideas and mainly forms and aesthetic foundations. The way to the worldwide reputation of Czech literature is based - due to the author - on the construction of this strong, intensive and complementary, multi strand complex anticipating the so-called postsecularity which has been manifested in the whole course of the 20th century.

\section{Key words}

the way of Czech literature towards worldwide reputation; similar processes in Slovak literature; the dual development of Czech literature; the permeation of the leftist avantgarde and spiritual literature 
Rok 2018 byl jedním z proslulých „osmičkových“ roků, které prý jsou pro české dějiny osudové. Pravda ovšem je, že spíše v modernější době, nebot' léta 1278, 1415, 1420, 1434, 1436, 1609, 1620, 1627, 1781 aj. nebyly méně významné než 1848, 1918, 1948 nebo 1968. V listopadu a prosinci 1989 jsme na některých transparentech demonstrantů viděli jako doklad mytičnosti osmičkových roků spojení 1968 a 1989 (obrácená „devítka“ je vlastně „šestka“). Významné roky jsou v českém prostředí často vzpomínány jako vítězství i prohry a často „slavné porážky“ jsou často významnější než Pyrrhova vítězství. Pokud ponecháme stranou aspekty numerologie, stejně jako hypotézy, že politické zvraty jsou spojeny se změnami ve vesmíru, které mění lidskou psychiku a vedou k masovým hnutím a brutálnímu násilí, zůstává faktem, že zejména ve 20. století byla léta s osmičkou pro české prostředí významná.

Rok 1918 vzpomínáme paradoxně v situaci, na niž mnozí, byt’ spíše potichu, upozorňovali: v České republice se oslavuje založení státu, který už neexistuje, který jsme sami zničili a který zanikl již dvakrát a také se vnitřně podstatně proměňoval i vinou jeho vedení, naposledy v letech 1992-1993, kdy se rozpadl v podstatě protiústavně. Podle některých názorů tedy Česká a Slovenská federativní republika (nový název již signalizoval cestu od federace ke konfederaci) právně nepřestala existovat, nebot při jejím zániku nebylo dbáno platné ústavy, zejména článku o referendu jako jediném nástroji event. zániku státu. ČSFR však byla rozdělena na základě nového ústavního zákona, který byl v přímém rozporu s výše zmíněným ústavním zákonem o referendu.

V této souvislosti jsme mohli číst více či méně zastřená tvrzení, že samotný vznik Československa byl vlastně omyl, že meziválečné Československo nebylo vzorem demokracie, jak se někdy tvrdí, ale naopak útvarem, v němž se potlačovala práva menšin, že byl založen na falešné ideologii čechoslovakismu a že rozdíly mezi Slováky a Čechy a rozpory mezi nimi jsou tak hluboké, že existence společného státu již proto nebyla perspektivní, že zánik byl již od počátku vtělen do jeho základu. Naopak se doceňuje Rakousko-Uhersko jako širší vlast a jako důležitý geopolitický faktor mezi Německem a Ruskem, jehož absence způsobila další tragédie 20. století, takže neinformovaného někdy napadá, že vlastně není ani co slavit, spíše rok 1918 může být pokládán za další českou porážku a slepou vývojovou uličku. S tím také souvisí dnes v historiografii módní hry na „kdyby“, takže sama existence Československa může být pokládána za příčinu druhé světové války. ${ }^{1}$

Když pomineme ideologické důvody takových tvrzení, často instruovaných a inspirovaných odjinud, nemůžeme neuznat, že základy Československa měly své slabiny, ale to ještě neznamená, že neměly šanci. Kritikové Československa také ignorují samo fungování monarchie, zdůrazňujíce pouze skutečné i potenciální klady, ale zcela opomíjející národní a geopolitické problémy spojené napřs. se stále větší závislostí na Německu a odporem k uznání práv jiných národů. Pro poněkud propagandistické tvrzení o monarchii jako žaláři národů najdeme jak podpůrné argumenty, tak polehčující okolnosti, ale fungování tohoto celku v momentu válečné zátěže nebylo možné, stejně jako další existence Ruské ř́íse v její podobě z válečných let 1914-1917. Jednou z cest, jak prověřit, byt’ dílčím

1 Viz Jak básně spolkly politiku. Milena Bartlová, Václav Bělohradský a Ondřej Slačálek v debatě Salonu. Zredigovaný přepis diskuse. https://www.novinky.cz/kultura/salon/474574-jak-basne-spolkly-politiku-milena-bartlova-vaclav-belohradsky-a-ondrej-slacalek-v-debate-salonu.html. Přístup 4. 8. 2018. 
způsobem, význam existence Československa, je zkoumání různých vrstev jeho života, jejich významu a hodnoty.

Všeobecně přijímaným názorem je, že Československo let 1918-1938 znamenalo rozkvět kultury, umění a také krásné literatury jako jeho druhu. Je zřejmé, že klíčovým problémem Československa byly národnostní menšiny, zejména německá, v pohraničí zemí Koruny české spíše většina, a vztah česko-slovenský. Není naším úkolem se k tomu kvalifikovaněji vyjadřovat, nebot to je spíše doména historiků a politologů, jen odkazujeme k ediční sérii Brněnské texty k slovakistice a k našemu syntetickému pokusu, kde se tyto vztahy z mnoha aspektů traktují. ${ }^{2}$ Zajímavý pohled ze strany přinesl kdysi badatel tragického osudu Valerij Vilinskij z rodiny brněnského emigré, rusisty Sergije Vilinského, o němž a o nichž jsem vícekrát psal. ${ }^{3}$

I někteří liberálnější slovenští historikové tvrdí, že Československá republika přinesla Slovákům více než Čechům, jiní zase poukazují na to, že Češi se snažili zbavit Slováky národní identity (čechoslovakismus), dokonce ovlivňovat jejich jazyk a oslabovat vliv katolické církve. S tím lze jen stěží polemizovat, zvláště když si na pozadí uvedené knihy V. Vilinského, kde se píše o konstruování Čechoslováka, uvědomíme, že v pojetí čechoslovakismu, tedy ve vytváření nového národa a dílem i jazyka a zanikání dvou dosavadních národů, se vlastně anticipovaly i jisté dominantní snahy dnešních elit v podobě oživené eugeniky - řízeného vzniku nového Evropana s podstatně změněnou identitou.

2 Viz naši soubornou stat Dlhá a bohatá tradícia. História a klúčové problémy brnianských česko-slovenských konferencii (1997-2017). Slovenské pohlady 2018, č. 3, s. 27-33 a Slovakistické reflexe. Brno: Česká asociace slavistů, Jan Sojnek-Galium, 2017.

3 VILINSKIJ, Valerij: Rus se dívá na ČSR. Praha: Václav Petr, 1931. Pro zajímavost: autorem obálky je malîr, sochař a architekt Josef Kaplický, otec proslulého architekta Jana Kaplického (1937-2009). Viz naši stat Ruský emigrant se dívá na meziválečné Československo a česko-slovenský vztah. In: Český a slovenský kulturní a politický prostor (vzájemnost - nevzájemnost, vstřícnost - rezistence, ústup - expanze). Ed. Ivo Pospísili. Výkonná redaktorka Lenka Paučová. Brno: Česká asociace slavistů, Jan Sojnek-Galium, 2017, s. 151-161. Další jeho práce: Ruská revolúcia. V rukopise poslovenčil Vojtech Hatala. Trnava: Spolok sv. Vojtecha, 1936; Unionizmus. Do slovenčiny upravil Ladislav Šulgan-Lazovský. Trnava: Spolok sv. Vojtecha, 1932. Týž: Slovanství, unionismus, orelstvo. Brno 1932; Ruský národ a sjednoceni církví. Olomouc: Apoštolát sv. Cyrila a Metoděje, 1928; K slovanské otázce. Tři koncepce slovanské vzájemnosti. Praha: Václav Petr, 1930; V Rusku boj truá... (Politické vraždy, procesy a spiknutí v SSSR). Praha: Václav Petr, 1933; Ruská revoluce 1825-1936. Přerov: Knihkupectví společenských podniků, 1936. Viz také naše předchozí studie: Sergij Vilinskij an der Masaryk-Universität in Brünn: Fakten und Zusammenhänge. In: Wiener Slavistisches Jahrbuch, Bd. 42, 1996, s. 223-230; Významné osobnosti naši univerzity. Zakladatel literárněvědné rusistiky na Masarykově univerzitě (Sergij Grigorovič Vilinskij, 1876-1950). In: Universitas, 2000, č. Supplementum 2, s. 36-38; Dva moravšti slavisté: Alois Augustin Vrzal a Sergij Grigorovič Vilinskij. Slavia Occidentalis 57, 2000, s. 219-233; Izmenenije temy $i$ metoda - Sergij Vilinskij v Universitete im. Masarika. In: Russkij jazyk kak inoslavjanskij, vypusk IV, Sovremennoje izučenije russkogo jazyka i russkoj kultury v inoslavjanskom okruženii. Beograd: Slavističeskoje obščestvo Serbii, 2012, s. 7-19. Viz ŽÁČEK, Pavel: V-101 (Valerij Vilinskij): agent, ze kterého se dalo žit. In: MEDVECKÝ, Matej (ed.): Posledné a prvé slobodné(?) volby - 1946, 1990. Zborník z odborného seminára. Bratislava: Ústav pamäti národa, 2006, s. 102-159; KAPLAN, Karel: Protistátní bezpečnost. 1945-1948. Historie vzniku a pưsobeni STB jako mocenského nástroje KSČ. Praha: Plus, 2015; DVOŘÁKOVÁ, Jiřina: Státni bezpečnost v letech 1945-1953. Praha: Úřad dokumentace a vyšetřování zločinů komunizmu, 2007. Vyčerpávající je monografie HULTSCH, Anne: Ein Russe in der Tschechoslowakei. Leben und Werk des Publizisten Valerij S. Vilinskij (1903-1955). Köln: Böhlau, 2010. Viz PUTNA, Martin C.: Hořký život Rusũ v Čechách. http://www.lidovky.cz/putna-horky-zivot-rusu-v-cechach-do8-/nazory.aspx?c=A111118_183244_ln_nazory_ape. Staženo 13. 8. 2016, 9:39. 
Krásná literatura jako součást kultury a umění v širokém slova smyslu budovala ve dvacetiletí 1918-1938 předpolí k světovosti. O tom málokdo pochybuje. Umění a jeho druhy se však mechanicky neřídí daty společenských a politických převratů, mají svou imanenci, autonomii, takže kvalita literatury pokračovala neztenčenou silou i dále v období druhé republiky a protektorátu, nabývala nových podob po roce 1945 a 1948, ale nikdy se zcela „neodstřihla“ od vědomí prvorepublikových hodnot, ač se to na první pohled nezdálo. Z oficiálních prohlášení dobových kritiků a ideologů, za oficiózními díly, jejichž sláva po pár letech vyprchala, byvši udržována jen ideologickou propagandou, zůstala spojnice, která vycházela z podivuhodné podoby prvorepublikové literatury, která zdaleka nebyla jednostrunná: vyznačovala se smyslem pro diskusi, jejíž součástí je ovšem i polemika, a tolerancí, ostatně jako do značné míry celý tehdejší společenský život v duchu Masarykova výroku o demokracii jako diskusi, úcta k oponentovi a soupeři nebo alespoň vědomí, že tato úcta musí být vyžadována, respektování většiny, ale i uznání menšině a uznávání jiného názoru a pohledu podle jiného Masarykova výroku "Já pán - ty pán“. I když se nový stát deklaroval jako pokračovatel spíše husitské a také českobratrské (ono proslulé vyvěšení vlajky s kalichem nad Pražským hradem Masarykem roku 1925 je toho provokativním emblémem - i takový byl; totéž praktikoval prezident Zeman v roce 2015 u př́ležitosti šestistého výročí upálení M. Jana Husa) a protestantské tradice, což bylo dáno jednak Palackého koncepcí českých dějin, jednak danostmi Masarykova života, demokracie vedla spíše ke kosmopolitnímu charakteru literatury napojené na bohémskou Francii a její moderní směry. Souvislost s americkým pragmatismem a na druhé straně s novopozitivismem, volnomyšlenkářstvím, fenomenologií a imanentními uměnovědnými metodami pak jako by neumožňovaly náboženským proudům výrazněji se profilovat. Překlady francouzské poezie nové doby z pera Karla Čapka, jenž se nakonec ani původním básníkem nestal, vytvořily, jak dokládají čeští básníci včetně Vítězslava Nezvala, moderní český básnický jazyk, tedy na bázi francouzských poètes maudits; ostatně Čapkovu oscilaci mezi francouzskou modernou, britským empirismem, americkým pragmatismem a ruským extrémismem jsem se pokusil v průběhu takřka dvaceti let ukázat v řadě studií. ${ }^{4} \mathrm{~V}$ té posledně uvedené jsem ve stopách Reného Wellka (1903-1995) a jeho koncepce duálního rázu anglické a české literatury ${ }^{5}$ poukázal na skrytou i otevřenou, zjevnou i méně zjevnou propojenost levicové literatury, která v meziválečném období dominovala, a katolicky orientované barokizující, duchovně nasycené literatury. Jinak řečeno: vidět levicově orientovanou modernu a avantgardu pokračující často opozičně

4 Viz naše studie: Jedna česko-ruská literárni spirála (Dostojevskij- Čapek - Těndrjakov). Čs. rusistika, 1990, č. 5 , s. 257-265; Dva poljusa bytija: anglo-amerikanskij empirizm-pragmatizm i „russkaja tema“ u Karla Čapeka. In: Związki między literaturami narodów słowiańskich w XIX i XX wieku. Pod redakcją Witolda Kowalczyka. Lublin: Wydawnictwo Uniwersytetu Marii Curie-Skłodowskiej, 1999, s. 225-233; Karel Čapek - przypadek prawie zapomnianego mistrza człowieczeństwa i tolerancji. In: Dyskursy i przestrzenie (nie)tolerancji. Pod redakcją Grzegorza Gazdy, Ireny Hübner, Jarosława Płuciennika. Łódź: Wydawnictwo Universytetu Łodzkiego, 2008, s. 109-118; Singularity and the Czech Interwar Essay among the Currents: František Xaver Šalda, Karel Čapek, and Jaroslav Durych. Primerjalna književnost 33, 2010, č. 1, s. 131-142.

5 Viz WELLEK, René: The Two Traditions of Czech Literature. In: Welek, René: Essays on Czech Literature. The Hague: Mouton, p. 30, 1963 (původně in: Slavic Studie., Ed. by A. Kaun and E. J. Simmons. Ithaca, N. Y.: Cornell University Press, 1943, s. 213-228). 
k hnutí devadesátých let 19. století jednosměrně a schematicky, jako by bez duchovního obsahu, by bylo asi přinejmenším nepřesné, nebot smyslovost, emocionalita, bojovnost není pouze znakem radikální avantgardy. Když pomineme propojení osobní, často velmi pevné (Halasovy vztahy ke katolickým básníkům, Nezval a Deml, Nezvalův sklon k magii a okultismu, jeho výtvarné práce, původně proletářský básník Josef Hora a jeho pozdější spirituální sbírky Itálie a Struny ve větru a jeho návraty ke klasice v původní tvorbě i překladu, Vančurova adorace středověku a renesance oproti buržoaznímu étosu, proměnlivá integrita Vladimíra Holana a jeho poezie dvacátých až čtyřicátých let včetně Vanutí a Kameni přicházís..., básnických reakcí na konec třicátých let 20. století, Terezky Planetové, Snu, jenž věnuje Velimiru Chlebnikovovi, ale i sugestivní básně Vltava v roce 1946, dále Diky Sovětskému svazu a Rudoarmejci až k poezii padesátých a šedesátých let vrcholící v Noci s Hamletem), klást proti sobě „pozemskou poezii“ a duchovní, spirituální, jak se to $\mathrm{v}$ posledních letech $\mathrm{v}$ různých podobách a z různých hodnoticích úhlů dělo, neodpovídá podle mého názoru skutečnosti, která je mnohotvárná a složitá. A víc než to: právě vnitřní propojení, byt často polemické, formovalo mezi těmito dvěma proudy nejen předpolí, ale i tvarující se celek světovosti, jenž vyústil často nečekaně v osobnostech a dílech druhé poloviny 20. století. Jakkoli se zejména v období druhé republiky spor těchto dvou linií ideologicky a politicky vyhrotil, at již autory těchto insinuací byl kdokoli a je zcela chybné, když se tyto reality dnes někdy opět zamlčují, otupují nebo retušují, při pohledu z odstupu a nadhledu se tyto hlubinné spojitosti vlastně paradoxně ještě zesilují, jak ostatně skrytě a paradoxně verifikoval vývoj i po roce 1945 a 1948.

V jedné stati jsem upozornil na pro někoho poněkud šokující názory Jaroslava Durycha, jež nám byly kdysi zprostředkovány v edici jeho často ani nepublikované publicistiky. ${ }^{6}$ Durych je významný právě tím, že se necitelně dotkl řady tabu, o nichž všichni věděli, ale z nějakých důvodů se je neodhodlali narušit; víme o řadě paradoxních, takřka šílených spojitostí, vnitřních propletenců a neskutečných zvratů, víme o ošidnostech a potměšilosti různě nahlížených a aplikovaných idejí, o jejich odvrácených stranách, o tragických lidských osudech s nimi spojených, ale ze strachu před odkrytím něčeho nevhodného a současně hrozivého a neodvratného se do třinácté komnaty bojíme vstoupit. V tomto smyslu se Durych zdá být tím, kdo nesl kůži na trh a toto vše obětoval. V tom se Durychova krajnost podobá nejen radikálním katolíkům typu L. Bloye a J. Demla, ale také velkým Rusům - ostatně o Gogolově nebo Dostojevského zájmu o katolictví a baroko se ví již dávno. Durych se vždy snažil o absolutní polohy: tak ve Výstražném slově k českým básnikům mu jde o skutečnou poezii nezávislou na politice dobové intelektuální elity. Havlíček je mu velký právě v porážce, samotě a smrti; doba po převratu roku 1918 je mu nesnesitelnou zástupem lůzy, konjunkturalismem frází o osvobození, hejslovanstvím,

6 Jaroslav Durych, publicista. Ed. Zuzana Fialová, doslov Jaroslav Med. Praha: Academia, 2001. Viz naši recenzi: Setkáni textü, které se vpijeji pod kůži (Jaroslav Durych publicista, připravila Zuzana Fialová, doslov napsal Jaroslav Med, vydala Academia, Praha 2001, 351 s.). HOST, 2002, č. 10, s. V-VI. Další naše pojednání o J. Durychovi: Kulturni zápisnik. Rozeklaná krása (Jaroslav Durych. Život, ohlasy, soupis díla a literatury o něm. Atlantis, Brno 2000). Univerzitní noviny, 2001, č. 1, s. 57-59; Singularity and the Czech Interwar Essay among the Currents: František Xaver Šalda, Karel Čapek, and Jaroslav Durych. Primerjalna književnost 33, 2010, č. 1, s. 131-142. 
sladkou Francií, Masarykem a Jiráskem (s. 16) ${ }^{7}$, česká krása je pro něj silná právě ve věcech intimního života: „Němec neni schopen vyjádřit lidskou vroucnost, proto musi odrazit od země do abstraktna za filozofickou vznešenosti" (s. 18). Českost je naopak silná v odloučení a skrytosti: „Česká krása je sui generis. Jejím štěstím je, že rostla z dobrého základu, ale odloučena od světa. Naším štěstím je, že nás nikdo neposlouchá, a tudiž neupadáme v pokušeni mluvit z okna. Až se najdou zvědavi cizinci, kteři budou chtít poslouchat a platit za to, bude hưr “" (s. 18). Podobně se lze tázat, zda není alespoň zrnko reality v zdánlivě toporném článku Kánon sexuality s věčně se opakujícím hypermanganem? Není kus pravdy i v utopickém vzývání chudoby? V České kultuře zas zaujme Durychův zuřivý odpor k evropeizaci (s. 25). Durych provokoval a provokuje dodnes a nezdo̊vodňujme tyto „úlety“ jen dobově nebo romantismem, ale berme je jako přirozené obnažování rubu věcí a jevů. To se týká i pojmu šmokové, za nímž se skrývají univerzitní profesoři, docenti apod. Na rozdíl od nadšenců vidí Durych v popřevratové Praze smutné město - člověk dobře chápe i logiku úvahy Proč mne mrzi být českým spisovatelem (s. 36-39); snad je pochopitelná i úvaha o Březinovi, kterak je jako básník i posmrtně deformován, brilantní je i studie valdštejnská: „Velikost lidská je nebezpečna sobě samé. Je principem lidstva, že ji musi vždy včas zničit. Je to jakýsi př́rodni nebo podpř́rodni zákon, který nutno mít na mysli, poněvadž je to zákon stálý a neměnitelny“ (s. 57). Durych citlivě pochopil podnětnost Hlaváčkovu (s. 67-68), příznačně charakterizuje Demla jako toho, v němž „vidime celý postup těženi stříbra od vstupu do šachty a práce ve štole, drceni v stoupách, mleti a promýváni až $k$ cestě do huti a celý tento temný, úděsný, hřmotný, dravý $i$ ohnivý proces ukazuje nám střibro v jeho tisicileté životnosti a dobyté slávě“" (s. 72). Durych dokázal jednou dvěma větami zobecnit, ale současně zůstat pevně utkvělý v životním detailu; takto je asi třeba číst i jeho studii o Prosperu Meriméem, ale i polemické kusy (Kratochvilná historie se svatým Václavem). Durych také době navzdory objevil Komenského barokismus a uvědomil si jeho španělské předlohy, zamyslel se nad silou arabské kultury (Tisíc a jedna noc), rozhořčil se - jako nejednou - v práci Sebrané poznámky („Nepatřim a nechci patřit do národa Husova..."); nutno uznat jeho právo, stejně však i právo jeho současníků cítit to podobně nebo naopak zcela jinak, protikladně. Objemná je komparativní studie o Březinovi a Dykovi: Durych tu po mém soudu mistrovsky sklenul oblouk doslova od pólu k pólu. Stále aktuální je i Durychovo úsilí o důstojnost básnického stavu: škoda, že se těmto slovům nenaslouchá více také nyní (mimo jiné ve smyslu podivné „povinnosti“ básníky za každou cenu politicky hodnotit). A přímo zjevením je drobná stat z roku 1947 o Grahamu Greenovi (s. 116-117). Druhý oddíl začíná příznačnou statí Řád svobody, v níž katolickou církev autor pokládá za ochránkyni svobody a „výspu, na které i ti nejstatečnějši bojouníci rádi odpočívaji" (s. 123). Kritika Rádlovy filozofie je i kritikou Čapků („Rozhodně doporučujeme tuto filozofii Robotům“). Pozoruhodné jsou však zejména Durychovy úvahy o komunismu, např. Čekám na slovo osvobozujici: „Komunismus má nezbytnou a prirozenou vlastnost velkého lidového revolučního hnuti: nedostatek vnitřni svobody [...] Germánská disciplína počtářských pravidel a ruská ezoterická hysterie se spojuji v projevech komunismu ve zvláštni masochistickou morálku, která by se ve mnohém podobala některým praktikám asketickým“ (s. 130-131). A Durychův příspěvek do proslulé ankety Proč nejsem

7 Tento citát i následné citace vyznačené číslem strany v závorce pocházejí z publikace Jaroslav Durych, publicista. Op. cit., 2001. 
komunistou, který ani demokrat Peroutka nedovolil otisknout, nebot při všem odstupu to bylo hodnocení paradoxně pozitivní, ale zase zcela organicky vyrůstající z Durychova naturelu a odpovídající tehdejší úrovni znalostí, ale obsahující i pozoruhodné souvislosti a krátká spojení. Prorocká jsou Durychova slova v článku Revoluce z roku 1925, mráz běhá po zádech z dělení lidí na A, B a C; nemluvě o výroku, že „hlavni, nejtěžši a nejbolestivějši funkce veškerého lidstva jsou dvě: ženám bylo uloženo rodit děti, mužům zase myslit" (s. 110). Začtěme se však i do věcí urážlivých, zcela nepřijatelných, jako je známý článek Pláč Karla Čapka (1937); Durych je zjevně přívržencem národních principů a nevěří nějakému obecnému evropanství (s. 224); známý je jeho odpor k Švejkovi, příznačné jsou jeho výzvy prezidentu Masarykovi a později Benešovi ve věci českých katolíků a katolické církve - patří sem i nepřijatelný článek z roku 1940 Př́klad Německa, stejně jako články proniknuté tu více tu méně skrytým antisemitismem. Nabízí se tu však šokující množství podnětů k dalšímu studiu: třeba spojitost baroka a Durychova stylu (sám píše, jak tento styl pracně, racionálně vyvíjel), souvislosti se španělskou a německou literaturou, obrovitý kontinent propastného ruského myšlení za Durychovými zády, vztah k reformaci a protestantismu, složité věci, které by dokázaly vyčerpat i sehraný, multidisciplinární badatelský tým.

Jestliže se poměrně mnoho psalo o vztahu české moderny a avantgardy a slovenských davistů (Daniel Okáli, Vladimír Clementis, Ján Poničan, Andrej Sirácky, Mikuláš Furdík, později k jejich okruhu patřili i Ladislav Novomeský, Gustáv Husák nebo Eduard Urx aj.), nelze pominout ani spojitosti české katolické literatury a slovenských katolických autorů a z nich zejména těch, kteří byli například studiem spjati s českým, pražským prostředím.

Pavol Strauss (1912-1994), i když bývá tradičně řazen do kontextu slovenské moderní katolické literatury či, jak se tomu někdy říká, slovenského katolického literárního hnutí třicátých a čtyřicátých let 20. století, tedy k autorům, kteří na Slovensku prožívají od devadesátých let minulého století konjunkturu, jako jsou Rudolf Dilong, Pavol Gašparovič Hlbina, Pavol Ušák Oliva, Ján Silan a další, je jevem zcela samostatným, jehož poetologické a myslitelské kořeny jsou různorodé povahy, ale spolu vytvářejí integrální celek opírající se především o poetiku expresionismu, ale zasahující také celostní atmosféru modernisticko-avantgardního období. Také pozornější lektura P. Strausse a podobných českých jevů ukazuje, že netřeba od sebe oddělovat ani jevy mentálně a světonázorově odlišné nebo často i protikladné: v českém, patrně více než v slovenském prostředí nebylo v meziválečném období ani později řídkým jevem, že si byli lidsky i tvořivě blízcí autoři katoličtí a levicově radikální. Je to tím, že ideové a tvarové principy, které se potom normativizovaly a nabývaly čítankových podob, měly svůj vývoj: na jedné straně čeští katolíci, kteří se postupně v důsledku vlastních vstřícných kroků a podobných pohybů protichůdné strany hradní alespoň načas identifikovali s podobou nového státu, na straně druhé i radikálně levicové, ba přímo komunistické hnutí mělo své peripetie a střety: není proto divu, že i autoři takto zaměření byli - zdánlivě paradoxně - znechuceni událostmi po únoru 1948, kdy vlastně jejich strana zvítězila způsobem, o nějž se dosud vedou spory, ale který vedl k systému, jejž ani někteří vzdělaní vyznavači této ideologie nepřijímali - zejména umělci (Jiří Kolář, Ludvík Kundera, Václav Zykmund, Ivan Blatný, František 
Halas aj.) nebo k nim měli výhrady a sami se později stali terčem útoků mladých radikálů (Vítězslav Nezval, Konstantin Biebl, František Halas, Jindřich Honzl, Ludvík Frejka, Jiří Weil, který jako jeden z prvních upozornil na podstatu Stalinovy diktatury v situaci, kdy ji většina západoevropských intelektuálů opěvovala). ${ }^{8}$ Někdy tam hrála značnou úlohu i trockistická ideologie obsažená zejména v knize Stalinova oponenta, později na jeho popud zavražděného v Mexiku, Lva Davidoviče Trockého-Bronštejna (1879-1940) Zrazená revoluce: co je SSSR a kam spěje (viz čes. vyd. 1937). ${ }^{9}$

Sám Strauss se v době před konverzí (1942) dal ovlivňovat židovskými autory německého jazyka, ale zvláštností českého prostředí, zejména pražského, ale i jiného, bylo, že řada starých židovských rodin se postupně asimilovala a komunikovala česky, stala se „českými Židy“, většinou také konvertovala z judaismu, většinou ke katolictví, ale ne vždy. To se týká i jmenovce Oskara Bauma, přírodovědce Jiřího Bauma (1900-1944, zahynul v koncentračním táboře ve Varšavě), známého, zejména afrického cestovatele, a hlavně rodiny Langrů, z níž pocházeli významní čeští spisovatelé - vojenský lékař, dramatik a prozaik, československý legionář MUDr. František Langer (1888-1965) a jeho mladší bratr Jiří (Georg) Mordechaj Ze'ev (1894-1943), který se dramaticky vrátil k judaismu a zemřel v dnešním Izraeli. Pokud jde o české spojitosti, neodmítal bych vazby na to, co se tehdy v Praze vydávalo, tedy nejen Nezval a poetisté, ale také poezie spirituální, jak bylo nejednou doloženo. ${ }^{10}$

Pokud výše uvedená fakta a konstatované spojitosti ukázaly na ideologické kontroverze i propletence radikální avantgardy a duchovních proudů literatury, v oblasti tvaru, poetiky je propojenost zřetelnější. Na jedné straně oscilovala mezi tradici a modernou, konzervatismem a avantgardismem v neobarokismu Jaroslava Durycha, jenž navazuje na nikdy nevysychající proud barokní poetiky, jenž zasáhl i český romantismus (K. H. Mácha) i realismus (Jakub Arbes a jeho romaneta), snad dokonce i moderní písňové texty, jak to, možná s jistou nadsázkou, předpokládal kdysi Zdeněk Rotrekl, ${ }^{11} \mathrm{v}$ archaizujícím stylu Vladislava Vančury, v podstatě ve všech jeho prózách od poetismu Amazonského proudu až k novelistickým drobnokresbám a historickým obrazům. Styl zde signalizu-

8 Jde o romány Moskva-hranice (1937) a Dřevěná lžice (napsáno 1949, vyd. 1992), viz např. naše texty: Nezbytí kritického myšlení (Weil - Orwell). Právo lidu, 18. 12. 1991, s. 6; Stádnost a intelekt (Jiři Weil: Moskva - hranice, Praha 1991). Lidová demokracie, 2. 10. 1991, s. 5; Bohové jsou zlí.. (Jiří Weil: Dřevěná lžíce, Praha 1992). Rovnost 12. 1. 1993, s. 5; Podoby a proměny židovství:Jiři Weil (1900-1959). Novaja rusistika, 2017, č. 1, s. 81-93; Zborcené iluze (G. Orwell: Hold Katalánsku, Praha 1991). Lidová demokracie, 24. 10. 1991, s. 5; Shakespeare, Tolstoj a Orwell. Lidová demokracie, 11. 3. 1992, s. 10; Zvíreci tvář člověka (G. Orwell: Farma zvírat, Praha 1991). Zemědělské noviny, 27. 1. 1992, s. 4; George Orwell. Tematická jednotka pro střední školy. Brno: CERM, Akademické nakladatelství, 1994.

9 Ve speciální stati (Pavol Strauss a hrst českých souvislostí. In: Pavol Strauss a katolícka moderna. Ed. Ján Gallik. Nitra: Ústav stredoeurópskych jazykov a kultúr, Fakulta stredoeurópskych štúdií, Univerzita Konštantína Filozofa, 2014, s. 91-109) jsem se pokusil propojit tvorbu tohoto slovenského tvůrce nejen s českou tradicí katolické literatury první republiky, ale tak s jevy druhé republiky (1938-1939) a tzv. protektorátu (1939-1945), a to v podobě zvláštní odrůdy psychologické existenciální prózy.

10 STRAUSS, Pavol: Za mostom času (Písanie bez konca). Košice: Verbum, 1993.

11 Viz náš komentář Čteme si v knihách brněnských autorů. Rotrekl, Zdeněk: Barokni fenomén v současnosti. TORST, Praha 1995. 232 s. KAM, příloha KAM v Brně, 1995, č. 8. Dokládá to i první teoretická kniha dnes slavného Igora Smirnova Chudožestvennyj smysl i evoljucija poetičeskich sistem (Moskva 1977). 
je ovšem ideologický záměr: u Durycha je jeho neobarokismus výrazem jiného názoru na vztah katolicismu a protireformace a osudu českého národa, v př́padě Vančurově je jeho adorace středověkých ctností a renesanční životní plnosti skrytým výrazem jeho levicové antiburžoazní ideologie, jakoby v duchu Heglova zákona negace negace - hledá vnitřní spojitost nového člověka s rytî́skými ctnostmi a renesančním hedonismem oproti údajné měštanské omezenosti, spojené často s protestantismem. Ostatně o problém titanismu se zajímal nejen V. Černý, ${ }^{12}$ ale také T. G. Masaryk, jenž plánoval knihu o velkých básnických osobnostech včetně Byrona a Goetha.

Propojenost levicové avantgardy a katolického duchovního proudu literatury za první Československé republiky jako předpokladová struktura vedoucí k světovosti do jisté míry anticipovala jevy, které sice začaly vznikat již v první polovině 20 . století a někdy i dříve (např̀ $\mathrm{v}$ podobě konverze intelektuálů ke katolicismu), ale rozvinuly se později jako tzv. postsekularismus. ${ }^{13} \mathrm{~V}$ referátu, který jsem přednesl na varšavské konferenci o postsekularismu The Experience of Faith in Slavic Cultures and Literatures in the Context of Postsecular Thought, jež se konala ve dnech 16.-17. 10. 2017 a kterou organizovaly ústavy západoslovanských a jihoslovanských studií a Fakulta polonistiky Varšavské univerzity spolu s Polskou akademií věd a Slovanskou nadací, jsem se zabýval slovanským a zvláště ruským specifikem postsekulárních jevů a postsekularismu jako myšlenkového směru. Kromě referátů se tu konaly i panelové diskuse a tematické moduly, jichž se zúčastnily osobnosti z několika zemí, především filologové, ale také politologové. ${ }^{14}$

Je nevyhnutelné neignorovat problémy ve vztahu mezi metodologií a terminologií: pojmy jako postsekularita, postsekulární na straně jedné jako výraz objektivní situace a postsekularismus a postsekularistický na straně druhé, což je výrazem spíše subjektivního vidění a myšlenkové tendence. Totéž se týká prefixu „post“, jenž nese podtext spodního proudu jistého návratu obohaceného o prošlou etapu sekularizace. Náboženství jako takové může hrát reálnou roli pouze $\mathrm{v}$ teokracii - tendence jako postsekularismus, jenž je dnes ve světě viditelný, může návraty k náboženství realizovat jen do určité míry. Je to spíše záležitost teologie. Jestliže je v sekulární společnosti sféra náboženství do značné míry vymezena nebo limitována materialistickými a racionalistickými koncepty, neznamená to ještě, že by právě náboženství nemohlo hrát scelující, holistickou roli. Tu se pokoušelo hrát v dějinách již vícekrát, např. tím, že se zapojovalo do primárně sekulárních procesů, např. konstituování moderních národů (u nás tzv. vlastenečtí katoličtí kněží).

12 Viz ČERNÝ, Václav: Essai sur le titanisme dans la poésie romantique occidentale entre 1815-1850. Prague: Orbis, 1935.

13 Viz naše studie Discussions, Commentaries and a Specific Project in the Panel Secularization, Desecularization, Postsecularism jako fragment Panel: Secularization, Desecularization, Postsecularism. In: http://postsecularstudies.pl/Round-Tables.htmlx. The Secular, the Sacral, and the Three Stages of Postsecular in Russian Literature: The Past and the Present. In: The Experience of Faith in Slavic cultures and Literatures in the Context of Postsecular Thought. Eds. D. Sosnowska - E. Drzewiecka. Warszawa: Wydawnictwo Uniwersytetu Warszawskiego, 2018, s. 178-188. Viz také informaci v naší souhrnné studii Politická a akademická objednávka v literární vědě a dvě témata: postsekularismus a ekfráze. In: Kontexty literární vědy VIII. Eds. I. Pospíšil - M. Zelenka - L. Paučová. Brno: Literárněvědná společnost; Tribun EU, 2018, s. 143-162.

14 Viz zmíněný text in: http://postsecularstudies.pl/Round-Tables.htmlx (můj text: Panel: Secularization, Desecularization, Postsecularism). Viz moji studii Politická a akademická objednávka v literární vědě a dvě témata: postsekularismus a ekfráze. 
V Rusku roku 1909 vychází sborník o ruské inteligenci (sám pojem ve významu „vyhraněná společenská skupina“ je ruský; angl. „intelligentsia“) Milniky (rus. Vechi), v němž se část ruských filozofů původně materialistické a legálně marxistické orientace (S. Frank, N. Berd’ajev, S. Bulgakov aj.) vrací k náboženským východiskům a ukazuje, že zaměření ruské inteligence na západní pozitivismus, materialismus, marxismus a ateismus (sám Berd’ajev byl tzv. legálním marxistou a byl perzekvován) vedla ke katastrofě první ruské revoluce a k utužení jen mírně reformované autokracie. Náboženství bude stále přežívat, je věčné, pokud bude existovat jeho ontická př́ičina, tedy existenciální dimenze lidského života. Postsekulární stadium vývoje společnosti je právě realizací jednoho ze zásadních a nejkontroverznějších zákonů Hegelovy dialektiky, a to zákona negace negace.

Hledat však slepě inspiraci ve všem, co jen poněkud „zaváni““ náboženstvím nebo transcendentnem, je scestné: je rozdíl mezi politologem, religionistou, teologem a praktikujícim katolíkem, mezi vědeckou a konfesní pozicí, nemluvě o módách a tlaku masmédií. Když se např. mluví o religiozitě české společnosti jako o slabé a o českém národě jako o národě ateistů, jde o zjevnou hyperbolu, za níž ještě stojí rozdíl mezi českou, moravskou a slezskou částí státu i mezi jednotlivými kraji Čech, a hlavně mezi církevním praktikováním a vírou jako takovou. Když se například zmiňuje osobnost Milana Machovce (1925-2003), měl by se vidět v celém rozpětí jeho ideologického vývoje od poněkud ortodoxního marxismu přes revizionismus až k disidentství, od tvưrčího marxismu k filologické práci o Indoevropanech. ${ }^{15}$ Nemluvě o bonmotu s racionálním jádrem, že ateismus je - stejně jako náboženství - víra, ale v to, že Bůh není.

Klíčovou postavou v někdejším, bohužel nyní již zcela mrtvém dialogu marxistů a teologů byl učitel někdejší Vojenské akademie Antonína Zápotockého, marxista a později disident Vítězslav Gardavský (1923-1978), pídící se různými formami po základních existenciálních otázkách, a to v žánru vědecké rozpravy, ale také divadelní nebo rozhlasové hry. ${ }^{16}$

Když se uvádí přítomnost náboženství v umění jako nezbytná (viz např. koncepci Lva Tolstého, který napadal to, že moderní umění opustilo náboženské principy a uspokojuje chtíč, lze hovořit i o umění záměrně protináboženském, ateistickém, jak to kdysi vyjádřil tehdejší ředitel speciálního Ústavu vědeckého ateismu v Brně v sedmdesátých letech 20. století17 a celá produkce tohoto ústavu do roku 1989, kdy fungoval v rámci širší instituce - Ústavu pro výzkum společenského vědomí).

15 MACHOVEC, Milan: Indoevropané v pravlasti aneb Život našich předků podle porovnání jednotlivých jazyků. Praha: Akropolis, 2000. Podstatnou pozdní knihou M. Machovce je Filosofie tvář́ v tvár̆ zániku, která poprvé vyšla v brněnském nakladatelství Zvláštní vydání roku 1998, druhé kritické vydání v Akropolis 2006.

16 Bůh a nevěricí svět: $k$ problematice církvi a marxistického ateismu. Praha: Socialistická akademie, 1967; Bůh není zcela mrtev. Úvaha o křestanském teismu a marxistickém ateismu. Praha: Československý spisovatel, 1967, 1970. Něm. překlad: Gott ist nicht ganz tot. Betrachtung eines Marxisten über Bibel, Religion und Ateismus. München: Chr. Kaiser, 1968, 1969, 1970, 1971; existuje také španělský překlad z němčiny Dios no ha muerto del todo: reflexiones de un marxista sobre la Biblia, la religión y el ateísmo. Salamanca: Ed. Sigueme, 1972. Ještě je překlad švédský (Stockholm 1970). Jeho spis Hoffnung aus der Skepsis vyšla ve stejném mnichovském nakladatelství roku 1970 jako překlad českého spisu Naděje ze skepse. Praha: Svoboda, 1969. 
Problémem postsekularismu se různí badatelé zabývali intenzivněji od šedesátých let 20. století. Jednou z nejuznávanějších byla koncepce Jürgena Habermase (nar. 1929), hlavně z důvodu jeho popularity jako slavného německého neomarxistického filozofa známého teorií komunikace (Theorie des kommunikativen Handelns, 1981), modernistického diskursu (Der philosophische Diskurs der Moderne, 1985) a analýzy novějších stadií současného kapitalismu včetně německé situace (Legitimationsprobleme im Spätkapitalismus, 1973; Die Normalität einer Berliner Republik, 1997) a normativních modelů demokracie. Jeho studie o postsekulární společnosti je však ještě populárnějšśi, ${ }^{18}$ i když vznikla řada dalších, možná vynalézavějších a produktivnějších. ${ }^{19}$ Někteří píšou o „částečné víře“; možná bude přesnější hovořit o permanentně obnovovaném náboženském světovém názoru.

V uvedené speciální studii jsem se zabýval také specifickým postavením slovanských literatur v tomto procesu sekularizace a postsekularizace. Problém spočívá v tom, že na slovanském Východě sekularizace nebyla dokončena, takže i postsekulární procesy probíhají jinak, majíce volnější realizační cestu; někdy jde o pouhou obnovu sakrality. To se týká všech tří východoslovanských literatur, když pomineme celek rusínský, který je hodně odlišný hlavně historicky a kulturně; zejména se to však týká ruské literatury, která svůj náboženský ráz neztratila vlastně nikdy, i když projevy religiozity obecně a v kultuře zvláště byly v sovětském období silně potlačovány. Unifikační roli sehrálo tu zejména baroko, první styl a směr, který se na ortodoxním slovanském Východě prosadil, nehledě na jeho katolický původ a protireformační funkci. Od nejzazšího evropského Západu po nejzazší evropský Východ se prosadila především poetika baroka jako syntetického stylu, jenž zasáhl i vysloveně protikladná kulturní a politická hnutí, od anglického puritánství v díle Johna Miltona, biskupa Jednoty bratrské J. A. Komenského až k východoslovanským básníkům (Simeon Polockij, Silvestr Medvěděv, Karion Istomin aj.) pěstujícím tzv. „virši“, tedy polské barokní sylabické básnictví. ${ }^{20}$

V slovanských literaturách obecně a v ruské zvláště mluvíme o tzv. prae-post efektu nebo paradoxu. Týká se hlavně Rusů, ale přeneseně i jiných východních, jižních a dílem i západních Slovanů. V rámci tohoto termínu, který jsme vymysleli a který se občas používá i jinými, jsme v ruské literatuře rozlišili tři stadia postsakrálního vývoje a ukázali ho na příkladech ruského románu. Permanentní postsekulární návraty k sakrálnímu jádru umění a literatury mohou být doloženy v romantismu, alespoň v některých jeho proudech, v stříbrném věku, tedy v ruské moderně, také v teori a umělecké praxi (Lev Tolstoj, F. M. Dostojevskij) a znovu stopově po celé 20. století (B. Pasternak, M. Bulgakov) a znovu v období glasnosti a perestrojky. A silný proud postsekulárního stadia v podobě využívané církevní slovanštiny se objevuje v běžné literární praxi současných autorů,

18 HABERMAS, Jürgen: Secularism's Crisis of Faith: Notes on Post-Secular Society. New Perspectives Quarterly, 2008, Vol. 25, s. 17-29.

19 Viz např. RATTI, Manav: The Postsecular Imagination: Postcolonialism, Religion, and Literature. London New York: Routledge, 2013; AGAR, Jolyon: Post-Secularism, Realism and Utopia: Transcendence and Immanence from Hegel to Bloch. London - New York: Routledge, 2014; McCLURE, John A.: Partial Faiths: Postsecular Fiction in the Age of Pynchon and Morrison. Athens: University of Georgia Press, 2007; MOROZOV, Aleksandr: Has the Postsecular Age Begun? In: Religion, State \& Society, 2008, 36, s. 39-44.

20 Viz výbor z barokní poezie, kterou sestavil Václav ČERNÝ: Kéž hoři popel můj. Praha: Ml. fronta, 1967. 
kteří svým světovým názorem k religiozitě netíhli (Jurij Bondarev, nar. 1924, a jeho román Bermudský trojúhelnik, rus. Bermudskij treugoĺnik, 1999, ${ }^{21}$ nebo Jevgenij Vodolazkin, nar. 1964, s románem Laurus, rus. Lavr). Ve výkladu, na nějž jsme odkázali, jsme se zabývali všemi třemi stadii tohoto návratu, včetně vlády Petra I. a státního utilitarismu, spojování ruského osvícenství a klasicismu s religiozitou, náboženskými motivy u Puškina a děkabristů s jedinou výjimkou, jíž byly ideologie rigidního ruského sociáldemokratismu a později bolševismu, i když tu byla řada výjimek, včetně tzv. bohohledačství a bohostrůjcovství, jež zasáhly Rusko po porážce první ruské revoluce 1905-1907 v díle A. V. Lunačarského, Maxima Gorkého a dalších. Porevoluční postsekulární stadium je patrné v již zmíněném sborníku Milniky (rus. Vechi, 1909). Nedokončená sekularizace ateistické politické doktríny byla doložena u odpůrců stalinismu, jimiž byli především sám Lev Trockij a trockisté. ${ }^{22}$

Předčasně ukončený pokus Petra Arkadjjeviče Stolypina o hlubokou ekonomickou reformu, jíž se Rusko mohlo vyhnout revolucím roku 1917, občanské válce a možná i světové válce roku 1914, způsobil polarizaci společnosti a její radikalizaci, v níž byl postsekularismus ztlumen nebo zastaven. Nicméně poetika „nedokončenosti“ v ruské literatuře a její spekulativnost a hloubavost způsobily, že se postsekulární fáze znovu vrací nejen v době glasnosti a perestrojky, ale také později v ruském postmodernismu, i když často travestijně a aluzivně v dílech Vladimira Sorokina (nar. 1955) nebo Viktora Pelevina (nar. 1962) s jejich sklonem k travestované historicitě. Jurij Bondarev a jeho román Bermudský trojúhelnik byl už zmíněn v souvislosti s návratem k církevní slovanštině jako legitimní vrstvě moderního románu, ale nejen to: komunista Bondarev, programový odpůrce perestrojky i Jelcinova režimu, se cíleně vrací k pravoslaví jako ruské náboženské tradici, kterou se snaží syntetizovat s tradicií sovětskou, i když historická fakta tomu zjevně odporují, ale obě stojí v jeho očích vysoko nad odcizováním Ruska a jeho amerikanizací. To vše je demonstrováno na jazyce: vznešené vrstvy církevní slovanštiny (staroslověnštiny východoslovanské redakce) jsou kladeny proti vulgární ruštině zasahujících bezpečnostních sil (omonovců).

Zmiňovaný návrat k zatím poslední fázi postsekularismu se objevuje jako oživení středověké tradice a demonstrace nepřetržitého proudu času (Vodolazkinův „nehistorický román“). Jevgenij Vodolazkin (nar. 1964), sám jako žák D. S. Lichačova profesí medievista, tvoří díla připomínající naše označení „virtuální autenticita“, ${ }^{23}$ jak je prezentuje

21 Jazyk literárního díla jako axiologický nástroj: román Jurije Bondareva Bermudský trojúhelnik (K životnímu jubileu prof. Jána Doruly). In: Život slova v dejinách a jazykových vztahoch. Na sedemdesiatiny profesora Jána Dorul'u. Bratislava: Slavistický kabinet SAV, 2003, s. 265-278; Diachronni dimenze ruského literárního textu (Puškin - Bondarev - Grjakalov). In: LEPILOVÁ Květuše a kol.: Text a kontext. Brno: Repronis Ostrava, 2008, s. 86-107; Znovu k problému diachronni hloubky literárního textu. In: Jazyk a komunkácia v súvislostiach III. Red. Ol'ga Orgoňová. Bratislava: Univerzita Komenského, 2011, s. 11-19.

22 TROTSKY, Leon: The Revolution Betrayed. Sepsáno 1936, publikováno 1937; DEUTSCHER, Isaac: The Unfinished Revolution: Russia 1917-1967. New York: Oxford University Press, 1967.

23 Viz POSPÍŠIL, Ivo: Próza virtuální autenticity a existenciálního znejistění. In: Sborník prací filozofické fakulty brněnské univerzity. X, Řada literárněvědné slavistiky (Slavica litteraria), 2007, č. X10, s. 5-20; Týž: Trivialita a hledáni virtuálni autenticity jako nového dialogu. In: Dialog kultur IV. Sborník příspěvků z mezinárodní vědecké konference pořádané ve spolupráci se Slavistickou společností FrankaWollmana při FF MU v Brně a Českou asociací rusistů. Hradec Králové 23.-24. 1. 2007. Uspořádal Oldřich Richterek. 
také V. Sorokin nebo u nás Michal Viewegh nebo na Slovensku Viliam Klimáček: je to v podstatě kombince avantgardních a postmodernistických poetik s pozadím v groteskně absurdní literatuře. ${ }^{24}$

Znejistění a ambivalence jako základní rys postmodernistické poetiky, fáze, jež jsme nazvali postpostmodernismem nebo kvázipostmodernismem, se projevuje jak ve Vodolazkinově románu Laurus, tak v jeho v novějším románu Aviátor (Vzduchoplavec). ${ }^{25}$ Zájem o postsakralitu by nemusel být jen módním závanem, nebot sám předmět zkoumání má racionální jádro a v dnešní přelomové epoše by mohl mít klíčové postavení.

Situace české a zčásti i slovenské literatury meziválečného období, tedy první Československé republiky, ukazuje, že prostupování moderny, avantgardy a spirituality v krásné literatuře nese s sebou i další boční produkty estetické povahy, dává vývoji literatury nové impulsy a může budovat národní literaturu jako předstupeň k literatuře světové ve smyslu syntetickém i axiologickém. Jestliže vzpomínáme stého výročí vzniku Československé republiky, státního útvaru, jenž dodnes vyvolává rozporuplné reakce, bylo by užitečné si uvědomit, že přinesla - v návaznosti na již proběhlé procesy národního obrození a kosmopolitizace v 19. století - také nové kvality ve smyslu prefáze postsekularity v podobě ideové a tvarové rozeklanosti české literatury jako předpokladových vrstev světovosti, jevu, jenž se nyní stává objektem multidisciplinárního bádání.

\section{Literatura}

AGAR, Jolyon: Post-Secularism, Realism and Utopia: Transcendence and Immanence from Hegel to Bloch. London and New York: Routledge, 2014.

BRADBROOK, Bohuslava: Karel Čapek. In Pursuit of Truth, Tolerance, and Trust. Brighton: Sussex Academic Press, 1998.

Ústí nad Orlicí: Oftis, 2007, s. 21-27; týž: Na hranici fikce a nonfikce: virtuálni autenticita a tvorba Arnošta Vašícka. In: Almanach Nitra 2013. (14. ročník). Eds. a vedeckí red. Jozef Vladár - Natália Muránska. Nitra: Nitrianska odbočka SSS, 2014, s. 135-141.

24 Viz naše studie: Český kvázipostmoderní román: poetizace automatismu a zrozeni „nového človèka " (Př́pad nevěrné Kláry Michala Viewegha). In: Retoriki na pametta. Jubileen sbornik v čest na 60-godišninata na profesor Ivan Pavlov. Redakcionna kolegija Bojan Biolčev - Valeri Stefanov - Kalina Bachneva - Panajot Karagjozov - Janko Băčvarov. Sofija: Universitetsko izdatelstvo Sv. Kliment Ochridski, 2005, s. 498-504; Lekce tviơrčho psaní a kvázipostmodernistická poetika Michala Viewegha. Stil (Beograd) 4, 2005, s. 303-313; Quasipostmodernistyczny świat Michala Viewegha. In: Literatury słowiańskie po roku 1989. Nowe zjawiska, tendencje, perspektywy. Tom I. Transformacja. Pod redakcją Haliny Janaszek-Ivaničkovej. Warszawa: Elipsa, 2005, s. 81-88; Postmodernism and Quasipostmodernism (Michal Viewegh). Neohelicon 33,2006, č. 2, s. 37-44; Žánr prozaického deniku Michala Viewegha, poetika, žánrové tradice a souvislosti. Stil (Beograd) 10, 2011, s. 309-322.

25 VODOLAZKIN, Jevgenij: Lavr. Moskva: AST, 2013; VODOLAZKIN, Jevgenij: Aviator. Roman. Moskva: AST, 2016. Viz naše stati Aksiologičeskij fenomen v „neistoričeskom romane“ Jevgenija Vodolazkina „Lavr“. In: Revitalizace hodnot: umění a literatura II. Týmová monografie. Ed. Josef Dohnal. Brno: Tribun EU, 2015, s. 591-601; Fenomen svjazi literaturovedenija i literaturnogo tvorčestva: Jevgenij Ljackij i Jevgenij Vodolazkin na kontekstual'nom fone. In: Universalii russkoj literatury 6. Sbornik statej. Voronež: Izdatel'sko-poligrafičeskij centr „Naučnaja kniga“, 2015, s. 227-244; Znovuvytváréení ruského fenoménu na počátku 21. století: návraty a nová „nasvěcovaáni“. Novaja rusistika, 2014, č. 1, s. 181-187. 
BRADBROOKOVÁ, Bohuslava: Karel Čapek. Hledáni pravdy, poctivosti a pokory. Praha: Academia, 2006.

ČAPEK, Karel: Čteni o T. G. Masarykovi. Uspořádal Miroslav Halík, který knihu rovněž opatřil vydavatelskou a edičními poznámkami a vysvětlivkami. 2. vyd. Praha: Česká expedice: Riopress, 1998.

ČAPEK, Karel: Univerzitni studie. Praha: Československý spisovatel, 1987.

ČERNÝ, Václav: Essai sur le titanisme dans la poésie romantique occidentale entre 1815-1850. Prague: Orbis, 1935.

ČERNÝ, Václav (ed.): Kéž hoři popel můj. Praha: Mladá fronta, 1967.

DEUTSCHER, Isaac: The Unfinished Revolution: Russia 1917-1967. New York: Oxford University Press, 1967

DOLGAN, Marijan (ed.): Kriza revije „Dom in svet“leta 1937. Zbornik dokumentov. Ljubljana: Založba ZRC SAZU, 2001.

DURYCH, Jaroslav: Jaroslav Durych, publicista. Praha: Academia, 2001.

DVOřÁK, Miloš: Rodný kraj v dile Jakuba Demla. Život 5-6, List pro výtvarnou práci a uměleckou kulturu, roč. XIV, 1936, s. 106-111.

DVOǨÁKOVÁ, Jiřina: Státni bezpečnost v letech 1945-1953. Praha: Úřad dokumentace a vyšetřování zločinů komunismu, 2007.

GARDAVSKÝ, Vítězslav: Bůh a nevěřcí svèt: $k$ problematice církvi a marxistického ateismu. Praha: Socialistická akademie, 1967.

GARDAVSKÝ, Vítězslav: Bưh není zcela mrtev. Úvaha o křestanském teismu a marxistickém ateismu. Praha: Československý spisovatel, 1967, 1970.

GARDAVSKÝ, Vítězslav: Dios no ha muerto del todo: reflexiones de un marxista sobre la Biblia, la religión y el ateísmo. Salamanca: Ed. Sigueme, 1972.

GARDAVSKÝ, Vítězslav: Gott ist nich ganz tot. Betrachtung eines Marxisten über Bibel, Religion und Ateismus. München: Chr. Kaiser, 1968, 1969, 1970, 1971.

GARDAVSKÝ, Vítězslav: Naděje ze skepse. Praha: Svoboda, 1969.

HABERMAS, Jürgen.: Secularism's Crisis of Faith: Notes on Post-Secular Society. New Perspectives Quarterly. 2008, Vol. 25, s. 17-29.

HULTSCH, Anne: Ein Russe in der Tschechoslowakei. Leben und Werk des Publizisten Valerij S. Vilinskij (1903-1955). Köln: Böhlau, 2010.

JUŘÍČKOVÁ, Miluše: Dva horizonty: Sigrid Undsetová a česká recepce. Brno: Masarykova univerzia, 2011.

KAPLAN, Karel: Protistátni bezpečnost. 1945-1948. Historie vzniku a puisobeni STB jako mocenského nástroje KSČ. Praha: Plus, 2015

KAUTMAN, František: $O$ českou národní identitu. Praha: Pulchra, 2015.

LOUKOTKA, Jiří: O náboženstvi a uměni. Praha: Horizont, 1974.

MACH, Alexander: $Z$ d'alekých ciest. Fragmenty z memoárov. Martin: Matica slovenská, 2008.

MACHOVEC, Milan: Filosofie tvaárí v tvář zániku. Brno: Zvláštní vyd., 1998, druhé kritické vydání Praha: Akropolis, 2006.

MACHOVEG, Milan: Indoevropanév pravlasti aneb Život našich předků podle porovnáni jednotlivých jazyki. Praha: Akropolis, 2000.

MAREK, Pavel, ed.: Česká katolická moderna. Prostějov: Museum Prostějov - Olomouc: FF UP, 1998. 
MCCLURE, John: Partial Faiths: Postsecular Fiction in the Age of Pynchon and Morrison. Athens: University of Georgia Press, 2007.

MERHAUT, Luboš: Cesty stylizace v české literatuře na přlomu devatenáctého a dvacátého století. Praha: Čs. akademie věd, 1992.

POSPÍŠIL, Ivo: Aksiologičeskij fenomen v „neistoričeskom romane“ Jevgenija Vodolazkina „Lavr“. In: Revitalizace hodnot: uměni a literatura II. Ed. Josef Dohnal. Brno: Ústav slavistiky FF MU, 2015, s. 591-601.

POSPÍŠIL, Ivo: Baroko jako historicky vymezený fenomén a jako kulturni typ (Barokový slavizmus Milana Kopeckého a publicistika Jaroslava Durycha). In: Pons Strigoniensis. Studia. Nové interpretace českého baroka. A Cseh barokk új interpretrációi. Sborník z mezinárodní konference, Piliscsaba, 12.-13. května 2003. Nemzetközi konferencia, Piliscsaba, 2003. május 12-13. Esztergom - Piliscsaba: Pázmány Péter Katolikus Egyetem, 2004, s. 11-24.

POSPÍŠIL, Ivo: Diachronni dimenze ruského literárního textu (Puškin - Bondarev - Grjakalov). In: LEPILOVÁ Květuše a kol.: Text a kontext. Brno: Repronis, 2008, s. 86-107.

POSPÍŠIL, Ivo: Dlhá a bohatá tradícia. História a klúǔcové problémy brnianských česko-slovenských konferencii (1997-2017). Slovenské pohlady, 2018, č. 3, s. 27-33.

POSPÍŠIL, Ivo: Dva moravšti slavisté: Alois Augustin Vrzal a Sergij Grigorovič Vilinskij. Slavia Occidentalis 57, 2000, s. 219-233

POSPÍŠIL, Ivo: Dva poljusa bytija: anglo-amerikanskij empirizm-pragmatizm i „russkaja tema“ $u$ Karla Čapeka. In: Związki między literaturami narodów słowiańskich w XIX i XX wieku. Pod redakcją Witolda Kowalczyka. Lublin: Wydawnictwo Uniwersytetu Marii Curie-Skłodowskiej, 1999, s. 225-233.

POSPÍŠIL, Ivo: Fenomen svjazi literaturovedenija i literaturnogo tvorčestva: Jevgenij Ljackij i Jevgenij Vodolazkin na kontekstualnom fone. In: Universalii russkoj literatury 6. Sbornik statej. Voronež: Izdatel'sko-poligrafičeskij centr „Naučnaja kniga“, 2015, s. 227-244.

POSPÍŠIL, Ivo: Izmenenije temy i metoda - Sergij Vilinskij v Universitete im. Masarika. In: Russkij jazyk kak inoslavjanskij, vypusk IV, Sovremennoje izučenije russkogo jazyka i russkoj kultury v inoslavjanskom okruženii. Beograd: Slavističeskoje obščestvo Serbii, 2012, s. 7-19.

POSPÍŠIL, Ivo: Jazyk literárního díla jako axiologický nástroj: román Jurije Bondareva Bermudský trojúhelnik ( $K$ životnimu jubileu prof. Jána Doruly). In: Život slova v dejinách a jazykových vzt̉ahoch. Na sedemdesiatiny profesora Jána Dorulu. Bratislava: Slavistický kabinet SAV, 2003, s. 265-278. POSPÍŠIL, Ivo: Jedna česko-ruská literárni spirála (Dostojevskij - Čapek - Těndrjakov). Čs. rusistika, 1990, 5, s. 257-265.

POSPÍŠIL, Ivo: Karel Čapek - przypadek prawie zapomnianego mistrza cztowieczeństwa i tolerancji. In: Dyskursy i przestrzenie (nie)tolerancji. Pod redakcją Grzegorza Gazdy, Ireny Hübner, Jarosława Płuciennika. Łódź: Wydawnictwo Uniwersytetu Łódzkiego, 2008, s. 109-118.

POSPÍŠIL, Ivo: Na hranici fikce a nonfikce: virtuálni autenticita a tvorba Arnošta Vašícka. In: Almanach Nitra 2013. (14. ročník). Eds. a vedeckí red.: Jozef Vladár - Natália Muránska. Nitra: Nitrianska odbočka SSS, 2014, s. 135-141.

POSPÍŠIL, Ivo: Pavol Strauss a hrst českých souvislostí. In: Pavol Strauss a katolícka moderna. Ed. Ján Gallik. Nitra: Ústav stredoeurópskych jazykov a kultúr, Fakulta stredoeurópskych štúdií, Univerzita Konštantína Filozofa, 2014, s. 91-109.

POSPÍŠIL, Ivo: Podoby a proměny židovstvi: Jiř̌ Weil (1900-1959). Novaja rusistika, 2017, č. 1, s. 81-93. 
POSPÍŠIL, Ivo: Primerjalna književnost, srednjeevropski kulturni prostor in teorija literarne zgodovine. Primerjalna književnost 31, 2008, č. 2, s. 137-148.

POSPÍŠIL, Ivo: Próza virtuálni autenticity a existenciálního znejistěni. In: Sborník prací filozofické fakulty brněnské univerzity. X, Řada literárněvědné slavistiky (Slavica litteraria), 2007, č. X10, s. 5-20.

POSPÍŠIL, Ivo: Ruský emigrant se dívá na meziválečné Československo a česko-slovenský vztah. In: Český a slovenský kulturní a politický prostor (vzájemnost - nevzájemnost, vstřícnost - rezistence, ústup - expanze). Ed. Ivo Pospísili. Výkonná red. Lenka Paučová. Brno: Česká asociace slavistů, Jan Sojnek-Galium, 2017, s. 151-161.

POSPÍŠIL, Ivo: Sergij Vilinskij an der Masaryk-Universität in Brünn: Fakten und Zusammenhänge. In: Wiener Slavistisches Jahrbuch, Bd. 42, 1996, s. 223-230.

POSPÍŠIL, Ivo: Singularity and the Czech Interwar Essay among the Currents: František Xaver Šalda, Karel Čapek, and Jaroslav Durych. Primerjalna književnost (Ljubljana) 33, 2010, č. 1, s. 131-142. POSPÍŠIL, Ivo: Slovakistické reflexe. Brno: Česká asociace slavistů, Jan Sojnek-Galium, 2017.

POSPÍŠIL, Ivo: Slovinská tradice a současnost (Kriza revije „Dom in svet“ leta 1937. Zbornik dokumentov. Uredil Marjan Dolgan. Znanstvenoraziskovalni center Slovenske akademije znanosti in umetnosti, Ljubljana 2001. The Imagination of Terra Incognita. Slovenian Writing 1945-1995. Edited by Aleš Debeljak. White Pine Press, New York 1997). Opera Slavica 13, 2003, č. 1, s. 70-71.

POSPÍŠIL, Ivo: Znovu k problému diachronní hloubky literárniho textu. In: Jazyk a komunkácia v súvislostiach III. Red. Olga Orgoňová. Bratislava: Univerzita Komenského, 2011, s. 11-19.

POSPÍŠIL, Ivo: Znovuvytvářeni ruského fenoménu na počátku 21. století: návraty a nová „nasvěcováni“. Novaja rusistika, 2014, č. 1, s. 181-187.

POSPÍŠIL, Ivo: Žánr jako bezprostředni výraz autorovy osobnosti. Denik spisovatele F. Dostojevského a Šlépěje J. Demla. Slovenská literatúra, 1990, č. 4, s. 338-349.

POSPÍŠIL, Ivo - Zelenka, Miloš: René Wellek a meziválečné Československo. Ke kořenům strukturální estetiky. Brno: Masarykova univerzita, 1996.

PUTNA, Martin C.: Česká katolická literatura v evropském kontextu 1848-1918. Praha: Torst, 1998.

PUTNA, Martin C.: Česká katolická literatura v kontextech 1918-1945. Praha: Torst, 2010.

PUTNA, Martin C.: Hořký život Rusů v Čechách. http://www.lidovky.cz/putna-horky-zivotrusu-v-cechach-do8-/nazory.aspx?c=A111118_183244_ln_nazory_ape, staženo 13. 8. 2016, 9:39.

PYNSENT, Robert B.: Pátráni po identitě. Jinočany: H \& H 1996.

PYNSENT, Robert B.: Question of Identity: Czech and Slovak Ideas of Nationality and Personality. London - Budapest - New York: CEU Press, 1994.

PYNSENT, Robert B.: Tolerance and the Karel Čapek Myth. The Slavonic and East European Review 78, 2000, 3, p. 331-353.

RATTI, Manav: The Postsecular Imagination: Postcolonialism, Religion, and Literature. London - New York: Routledge, 2013.

STRAUSS, Pavol: Za mostom času (Písanie bez konca). Košice: Verbum, 1993.

ŠALDA, František Xaver: Z obdobi Zápisniku. Praha: Odeon, 1987-1988.

UHLE, Dorothea: Avantgarde, Zivilisationskritik und Pragmatismus in Karel Čapeks „Boži muka“. Frankfurt am Main - Berlin - Bern - Bruxelles - New York - Oxford - Wien 2006.

VILINSKIJ, Valerij: Rus se dívá na ČSR. Praha: Václav Petr, 1931. 
VILINSKIJ, Valerij: Ruská revoluce 1825-1936. Přerov: Knihkupectví společenských podniků, 1936. VILINSKIJ, Valerij: Ruská revolúcia. V rukopise poslovenčil Vojtech Hatala. Trnava: Spolok sv. Vojtecha, 1936.

VILINSKIJ, Valerij: Ruský národ a sjednoceni církví. Olomouc: Apoštolát sv. Cyrila a Metoděje, 1928. VILINSKIJ, Valerij: K slovanské otázce. Tři koncepce slovanské vzájemnosti. Praha: Václav Petr, 1930.

VILINSKIJ, Valerij: Slovanství, unionismus, orelstvo. Brno: Československý Orel, 1932.

VILINSKIJ, Valerij: Unionizmus. Do slovenčiny upravil Ladislav Šulgan-Lazovský. Trnava: Spolok sv. Vojtecha, 1932.

VILINSKIJ, Valerij: V Rusku boj trvá... (Politické vraždy, procesy a spiknutí v SSSR). Praha: Šolc a Šimáček, 1933.

VODOLAZKIN, Jevgenij: Lavr. Moskva: AST, 2013.

VODOLAZKIN, Jevgenij: Aviator. Roman. Moskva: AST, 2016.

VOISINE-JECHOVÁ, Hana: Dějiny české literatury. Jinočany: H \& H 2005.

WELLEK, René: Immanuel Kant in England. Princeton: Princeton University Press, 1931.

WELLEK, René: The Two Traditions of Czech Literature. In: WELLEK, René: Essays on Czech Literature. The Hague: Mouton, p. 30, 1963 (původně in: Slavic Studies, ed. by A. Kaun and E. J. Simmons. Ithaca, N. Y.: Cornell University Press, 1943, s. 213-228).

ŽÁČEK, Pavel: V-101 (Valerij Vilinskij): agent, ze kterého se dalo žít. In: MEDVECKÝ, Matej (ed.): Posledné a prvé slobodné(?) vol'by - 1946, 1990. Zborník z odborného seminára. Bratislava: Ústav pamäti národa, 2006, s. 102-159.

prof. PhDr. Ivo Pospíšil, DrSc.

Ústav slavistiky

Filozofická fakulta, Masarykova univerzita

Arna Nováka 1, 60200 Brno,Česká republika

ivo.pospisil@phil.muni.cz

Toto dílo Ize užít v souladu s licenčními podmínkami Creative Commons BY-SA 4.0 International (https://creativecommons.org/licenses/by-sa/4.0/legalcode). Uvedené se nevztahuje na díla či prvky (např. obrazovou či fotografickou dokumentaci), které jsou v díle užity na základě smluvní licence nebo výjimky či omezení příslušných práv. 
